\title{
Inter-Stakeholders Communication in the Implementation of Village Fund Programs: An Experience in Gorontalo Province, Indonesia
}

\author{
Sumarlin Adam ${ }^{1}$, Pattaling ${ }^{1}$, Sumarni Sumai ${ }^{2} \&$ Muhammad Obie $^{3}$ \\ ${ }^{1}$ Department of Communication, State Islamic University of Sultan Amai Gorontalo, Indonesia \\ ${ }^{2}$ Department of Communication, State Islamic University of Pare-Pare, Indonesia \\ ${ }^{3}$ Department of Sociology, State Islamic University of Sultan Amai Gorontalo, Indonesia \\ Correspondence: Muhammad Obie, Department of Sociology, State Islamic University of Sultan Amai \\ Gorontalo, Indonesia. Tel: 62-813-4579-0642. E-mail: obiclimber@gmail.com
}

Received: February 25, 2019 Accepted: April 22, 2019 Online Published: May 10, 2019

doi:10.5539/jms.v9n1p132 URL: https://doi.org/10.5539/jms.v9n1p132

\begin{abstract}
This study analyzed the patterns and models of communication that occur among stakeholders in the implementation of village fund programs; communication barriers that occur; and the implementation of the village fund programs itself with the communication patterns and obstacles that occurs. Data collection was done through non-participatory observation, in-depth interviews, focused group discussion, and literature review. The results showed that stakeholders in the implementation of village fund programs carry out formal and non-formal communication patterns. The communication model found was both linear and convergent models. The communication barriers could occur in communication from top to bottom, the bottom up, horizontally, and diagonally. There are various types of communication barriers that occur in implementing village funds, namely: personal, cultural, physical, and environmental barriers. The implementation of village funds requires the village community to act as the subject of development, thus requiring the participation of all village communities, starting from the stages of planning, implementation, monitoring, to preservation.
\end{abstract}

Keywords: communication, village fund programs, community empowerment, Gorontalo Province

\section{Introduction}

Through the ratification of Law Number 6 of 2014 concerning villages, villages are given a great opportunity to take care of their governance and the implementation of development to improve the welfare and quality of life of rural communities. The law positions the village as the spearhead of development and improvement of community welfare. Villages are given adequate authority and funding resources to be able to manage their potentials in order to improve the economy and prosperity of the community. Also, the village government is expected to be more independent in managing the government and various natural resources owned, including the management of financial and wealth belonging to the village. So much of the role received by the village, of course, is accompanied by great responsibility. Therefore, the village government must be able to apply the principle of accountability in its governance, where all end activities of the implementation of village governance must be accountable to the village community by the provisions.

The Central Government has budgeted a village fund that is large enough to be given to the village every year. In 2015, the village fund was budgeted at IDR 20.7 trillion, with an average of IDR 280 million per village. In 2016, the village fund increased to IDR 46.98 trillion with an average of IDR 628 million per village, and in 2017 it increased to IDR 60 trillion with an average of IDR 800 million per village (Indrawati, 2017). In terms of use, based on available data, 84 percent of village funds are used for the construction of rural physical facilities and infrastructure, as much as 6.5 percent for community economic empowerment, and the remainder for government and community social activities. Although infrastructure development can contribute to poverty reduction through choosing the type of infrastructure that has an economic impact, many villages were found to build village gates, village offices, or village fences that have little impact on the economy especially poverty reduction (Bappenas, 2017).

Looking at the evaluation of the village fund program implementation the previous year, the Minister of Village, Development of Disadvantaged Areas and Transmigration of the Republic of Indonesia issued the Republic of 
Indonesia Minister of Village, Development of Disadvantaged Areas and Transmigration Regulation on Priorities for Using Village Funds 2019. The Ministerial Regulation reaffirmed the commitment to use village funds which in article 4 paragraph 1 states that the use of village funds is prioritized to finance the implementation of programs and activities in the field of village development and empowerment of village communities (Kemendes, 2018).

Village funds in its implementation involve various stakeholders, both structural, consultant, and community. The structural path stakeholders involve state officials from the ministry level, the governor, the regency, to the village level, while the consultant line involves national consultants, provincial, regency, sub-district to local village companion. Meanwhile, the village community as a subject in the implementation of village funds is fully involved from the planning of activity ideas to the implementation and supervision.

The quality of implementing village funds in their implementation is inseparable from the quality of communication between stakeholders involved in it. Often encountered the implementation of village funds that are not on target, until the misuse of village funds, both by structural path stakeholders, consultants, to the community, is strongly influenced by the communication activities of the stakeholders.

It is because communication is an essential element in human life. Communication will arise if someone holds interaction with other people so that it can be said that communication arises as a result of the existence of social relations. This understanding implies that communication cannot be separated from human life, both as individuals and as a group. Rakhmat (1998) states that communication is a social process that is very basic and vital in human life. It is said to be fundamental because every human society, both primitive and modern, wishes to maintain an agreement on various social rules through communication. It is vital because each can communicate with other individuals to increase the individual's chance to stay alive. The essence of communication is to find and integrate the recipient and the sender for the specific message content (Siahaan, 1991). Communication is said to be effective if it has the expected effect of the communicant. It can only happen if the communicator knows correctly who the communicant is. Because one of the main principles of communication is that communication can only occur if there is an exchange of experiences between the parties involved in the communication process (Cangara, 2014).

Communication in the implementation of development, including the implementation of village fund programs, plays a significant role. Rogers et al. (1976) said that communication is still considered an extension of government planners, and its primary function is to get community support and their participation in the implementation of development plans. The village fund program is in principle conducting a release where the community is free to determine the direction of the village development according to their needs.

\section{Literature Review}

\subsection{Communication Patterns}

Rogers and Schoemaker in Mardikanto (1987) stated that communication is a process of delivering messages from the source to the recipient. This communication is described as a unidirectional processor linear communication model. Another model is the convergent communication model (Rogers \& Kincaid, 1981). This model is described as a two-way interactive process among participants. The communication model is defined as a process by which participants create and share information to form shared understanding so that relationships occur between them. Djamarah (2004) suggests that communication patterns can be understood as a pattern of relations between two or more people in sending and receiving messages in the right way so that the message in question can be understood.

Communication patterns can be distinguished into formal communication channels and non-formal communication channels (Purwanto, 2003). Formal communication channels are the process of delivering information from leaders to subordinates or from managers to employees. The transformation pattern of information can take the form of communication from top to bottom, communication from the bottom up, horizontal communication, and diagonal communication.

a) Communication from top to bottom. The flow of communication from top to bottom is generally related to the responsibilities and authorities in an organization. A manager who uses communication channels from top to bottom has the aim to direct, coordinate, motivate, lead, and control various activities at the lower level. According to Katz and Kahn in Purwanto (2003), communication from top to bottom has five main objectives, namely: i) Providing specific instructions or work instructions; ii) Providing information on why a work must be carried out; iii) Provide information about organizational procedures and practices; iv) Provide work 
implementation feedback to employees; and v) Presenting information about aspects of ideology in helping organizations instill an understanding of the goals to be achieved.

b) Communication from the bottom up. Communication from the bottom up means the flow of information comes from subordinates to the superordinates. To achieve successful communication from the bottom up, managers must genuinely have trust in their subordinates. According to Muhammad (2004), the purpose of communication upward is to provide feedback, give advice, and ask questions.

c) Horizontal communication. Horizontal communication is communication that occurs between parts that have an equal position in an organization. The purpose of horizontal communication is to persuade, influence and provide information to a department that has an equal position.

d) Diagonal communication. Communication involves two different levels of the organization. Diagonal communication is more widely applied in a large-scale organization, where there are interdependencies between parts or departments within the organization.

The other communication pattern is non-formal communication channels, namely communication channels that do not pay attention to hierarchy, rank, and position.

\subsection{Communication Barriers}

Constraints in communication internally in communicating according to Ludlow and Panton (1996) are the differences in perceptions between superiors and subordinates caused by perceptual distortion, namely differences in the way of thinking and ways of thinking between communicators and communicants during the communication process. Constraints in the form of restrictions on information conveyed by superiors to executors and leadership styles of superiors that are not under subordinate preferences are distortions caused by status effects, namely differences in social status among members of organizations that have a higher status in a hierarchy or organizational structure than with other members.

Constraints in the organization are also in accordance with communication disruptions that often arise in organizational communication according to Plunket and Atner (in Ruliana, 2014), namely communication disorders at the management level, that within the organizational management level there can be messages or information that are not fully run smoothly, both in terms of the direction of flow of information or communication patterns, both top down and bottom up. Another communication barrier that often arises is in the form of manager interpretation; that is, each manager has a mindset, related patterns and different ways of interpreting when interacting with subordinates.

Effendy (2002) suggests several factors that can inhibit communication, namely: First, disorders. There are two types of interference with the course of communication which by their nature can be classified as mechanical disturbances and semantic disturbances. Mechanical disorders are disorders caused by communication channels or environmental noise. An example is a dual sound interference on a radio plane, a snaking image or changing the television layer, letters that are not clear, the path of letters that are missing or upside down or pages that are torn in the newspaper. Whereas, semantic interference is a type of interference that is concerned with communication messages whose understanding becomes damaged. This semantic disorder is filtered into the message term or concept contained in the communicator, so there will be more semantic interference in the message. Semantic disorders occur in a sense.

Second, interest. Interest will make someone selective in responding to or living a message. People will only pay attention to stimuli that have to do with their interests. Interest not only affects our attention but also determines responsiveness. Our feelings, thoughts, and behavior are reactive attitudes towards all stimuli that do not correspond or conflict with interest.

Third, hidden motivation. Motivation will encourage someone to do something right with its desires, needs, and disadvantages. Desires, needs, and shortcomings of a person are different from other people, from time to time and from place to place, so because the motivation is different in intensity. The more appropriate communication with one's motivation the more likely the communication can be well received by the parties concerned. Conversely, the communicant will ignore a communication that is not following his motivation.

Fourth, prejudice. Prejudice is one of the hardest obstacles for a communication activity because people who have prejudice have not been suspicious and oppose communicators who want to communicate. In prejudice, emotions compel us to conclude based on suspicion without using a rational mind. Prejudice can not only happen to a race, as we often hear but also to religion, the political establishment, short words a stimulus that inexperience has given an unpleasant impression. 
Purwanto (2003) states that the inhibiting factors of communication can be grouped into four main problems, including 1) Problems in developing messages, including among others the emergence of doubts about the content of the message, less familiar with the situation, the existence of emotional conflict or challenging to appreciate ideas; 2) Problems in delivering messages, related to physical facilities to communicate; 3) Problems in receiving messages, including competition between sight and sound, uncomfortable seats, underexposed lights and other conditions that disrupt audience concentration; 4) Problems in interpreting messages, differences in background, vocabulary and emotional statements can lead to misunderstandings between the sender and the recipient of the message.

Constraints in communication can occur due to a factor of miscommunication. Kreitner and Kinicki (1995) mention the factors causing miscommunication as follows: 1) personality incompatibility or value system; 2) boundaries of unclear or overlapping work; 3) competition for limited resources; 4) insufficient exchange of information or communication; 5) interdependence in work (for example, a person cannot complete his work without the help of others); 6) organizational complexity (conflict tends to increase along with the increasing arrangement of work hierarchies and specialties; 7) regulations, work standards, or policies that are unclear or unreasonable; 8) the deadline for completion of work that makes no sense so that it is difficult to fulfill (unreasonable deadlines); 9) collective decision making (the more people involved in the decision-making process, the more potential for conflict); 10) decision making through consensus; 11) unbearable expectations; 12) do not resolve or hide conflicts.

\section{Research Methods}

The approach used in this study was a descriptive approach. The data collected was qualitative data. According to Soekanto (2010), a descriptive approach is intended to provide a detailed and precise description of the problem under study. Qualitative research instruments according to Satori and Komariah (2014) are "human instruments" or humans as informants and those who are looking for data and the main instruments of qualitative research are researchers themselves as spear data collectors. In line with that, Soekanto (2010) states that a qualitative approach is a method of research that produces detailed procedures, namely what is stated by the respondent in writing or verbally, and real behavior.

Informants as primary data sources in this study were selected using the snowball technique. According to Sugiyono (2015) in qualitative research, the sampling technique that is often used is Purposive Sampling and Snowball Sampling. The snowball technique is a technique of determining samples that are initially small in number, then enlarged. It is like a rolling snowball that has become big for a long time.

Data collection was done through observation, in-depth interviews, Focused Group Discussion-FGD; and literature review. Observation is making observations on the subject of the study openly (Sugiyono, 2009). This study chooses a non-participation observation method, namely observations made in which the researcher observes behavior from a distance without any interaction with the subject being studied (Satori \& Komariah, 2014).

Meanwhile, in-depth interviews are conversations with specific intentions (Moleong, 2007). In line with that, Satori and Komariah (2014) state that interviews are a technique of collecting data to obtain information extracted from data sources directly through conversation or question and answer. The purpose of conducting interviews is, among others: constructing about people, events, organizations, feelings, motivations, demands, concerns and others (Lincoln \& Guba, 1985; in Moleong, 2007). The Focused Group Discussion (FGD) method is to explore the topic of the problem in more depth through directed discussion. The literature study is needed to complete field data.

Data analysis is the process of systematically finding and compiling data obtained from interviews, field notes, and documentation, by organizing data into categories, describing into units, synthesizing, arranging into patterns, choosing which ones are important and which will be studied, and make conclusions so that it is easily understood by oneself and others (Sugiyono, 2015).

Data analysis aims to compile data in a meaningful way so that it can be understood. Patton (1990) argues that there is no correct way to organize, analyze, and interpret qualitative data. When data collection takes place, at the same time, researchers begin to analyze data. Data analysis is then continued after data collection has been completed in a certain period. When observations, interviews, and FGDs took place, researchers had analyzed the informants' answers. If the informant's answer after being analyzed feels unsatisfactory, the researcher will continue the question again, to a certain extent, obtained data that is considered credible (Sugiyono, 2009). 
Existing data was sorted, categorized, and grouped according to analysis needs. Data sorting was done by completing and transforming raw data written in field notes so that it becomes a regular report, completing information collected with other supporting sources.

\section{Results and Discussion}

\subsection{Patterns and Models of Inter-Stakeholders Communication in the Implementation of the Village Fund Programs}

\subsubsection{Inter-Stakeholders Communication Patterns}

The pattern of communication between stakeholders in the implementation of village fund programs can take place both formally and informally. Formal communication patterns that occur in implementing village funds can take place from top to bottom, from the bottom up, horizontally, and diagonally. The non-formal communication pattern can be a communication channel that does not pay attention to the hierarchy, rank, and position.

Downward communication is a communication pattern that takes place between superiors and subordinates. The downward communication pattern contains instructions from superiors, dissemination of rules and program policies, direction, and explanation of the program, as well as awards as feedback on the implementation of work to subordinates. In the village fund program, top-down communication has two paths whose main tasks and functions are different, namely: 1) structural paths, and 2) functional lines. The structural path is attached to the work unit in the government, starting from the village ministry as the national work unit, the provincial government as the provincial work unit, and the district work unit to the village. The communication pattern in this pathway runs structurally from village ministries to village administrations. Meanwhile, the functional communication channel involved consultants as community facilitators, starting from a national consultant team based in Jakarta, a provincial consultant team in each province, a regency facilitator team, sub-district facilitators, to local village facilitators. Communication is carried out massively in stages, both written through correspondence, or verbally. Formal communication is carried out from top to bottom, first done in writing, followed by oral communication as an affirmation or to clarify the intent of the letter that has been sent.

The upward communication pattern is communication carried out by subordinates to superiors. Information comes from the lower level to a higher level. Upward communication is related to the performance of subordinates usually in the form of reports, questions about work, complaints, delivery of ideas, suggestions, ideas from subordinates to their superiors. As with the downward communication pattern, the upward pattern of communication also occurs through the government's structural path, as well as the functional pathway assisting rural communities. However, the upward communication pattern through structural pathways is not as intense as in the functional path. The upward communication pattern in the structural pathway is more formal and bound by working hours in the government, while in the functional path, especially at the lowest level in the village, village facilitators do not know the working day. Village facilitators must accompany their assistants at all times in carrying out the process of community empowerment in the village. Thus, the village facilitator at any time also receives various information from below which then feels urgent as soon as he passes the information to his supervisor.

Reporting activities are the most common communication pattern carried out from the bottom up in the implementation of village fund programs. Unlike in structural lines, the upward communication pattern in functional lines is very intense and massive. Village facilitators are the lowest level in the functional level of consultants in the implementation of village fund programs. This functional personnel carries out the village empowerment process, starting from socialization, planning, implementation, to evaluating programs implemented in the village. The local village facilitators were more as village assistants in carrying out the empowerment process. In carrying out the process, the village facilitator must provide a report periodically to the levels above.

The practice of reporting by village facilitators to district facilitators, as direct supervisors of village assistants, is carried out in writing in the form of weekly reports, monthly reports, and year-end reports. In addition to the written report, if things were very urgent in the implementation of the empowerment process in the village, then the village facilitator immediately made verbal communication via telephone to the district facilitator.

Horizontal communication is a pattern of communication carried out between peers. In the implementation of village fund programs, horizontal communication patterns commonly occur among functional consultants in the context of mutual support for progress and problem-solving in the field. Horizontal communication patterns are 
carried out verbally rather than written. The pattern of verbal communication is done face to face or remotely via the telephone.

The practice of pattern communication is carried out based on friendship among fellow consultants where there are colleagues who need help from other colleagues in carrying out the program stages in their area. Ideally, the placement of consultants in each sub-district consists of 1 village facilitator in the field of empowerment and one village assistant in the technical field. However, due to lack of resources, there are often vacancies in technical assistance in a sub-district. Thus, the empowerment companion on duty alone to the sub-district with a technical assistant needs assistance from technical assistants who work in other sub-districts. Horizontal communication is also frequent among fellow consultants of village funds just sharing information about the progress of program implementation in their respective assignment areas or simply conveying outpouring of heart about the bittersweetness of carrying out the empowerment process in the village.

Unlike the top-down communication pattern that is more formal and contains orders or work instructions so that the obligation to follow up is attached, horizontal communication patterns are more informal and do not contain orders. In the pre-theater implementation of village fund programs, horizontal communication patterns reinforce peer solidarity. Requesting assistance to colleagues in the implementation of the village fund program is not an obligation or an obligation for other assistants to implement it, but rather as a soul calling to help others so that it strengthens togetherness and solidarity among fellow village facilitators.

The pattern of diagonal communication in the implementation of village fund programs can be seen in the interdependence between the work unit team starting from the national level in the village ministry to the lowest government at the village government level, with the accompanying consultant team from the national level to local village facilitators. The interdependence can be seen from the implementation of the stages of the empowerment process in the field carried out by the accompanying consultant, while the budget disbursement process at the state treasury office disbursement in the community is carried out by the government's structural path.

Disbursement of the budget in the State Treasury Office requires sure assistance progress so that the village government has a dependency on the results of assistance carried out by the consultant team. Likewise, the progress of budget realization in the field carried out by the implementing team requires assistance from consultants to ensure the realization runs following the prescribed mechanism.

\subsubsection{Inter-Stakeholders Communication Models}

The model of communication among stakeholders in the implementation of village fund programs can be found in both linear and convergent models. The linear model in the implementation of village fund programs can occur in both the structural and functional paths of the consultant. Communication patterns that are command or instructor from top to bottom that commonly occurs both in the structural path of government and functional consultants are the practice of linear model communication where communication only takes the direction of the boss to the subordinates that must be carried out. When a subordinate receives a letter from a superior whose character is an order or instruction to be carried out in the field, the subordinate has no choice but to carry out the instructions in the letter.

In contrast to written letters sent by superiors to subordinates, oral communication opens up more dialogue space to allow for two-way communication (convergent models). In implementing village fund programs, convergent model communication can be found during coordination meetings, both at the provincial level coordination meetings involving all the provincial consultant teams and district facilitators, as well as coordination meetings at the district level which present all district facilitators and village facilitators. Through coordination meetings, various parties dialogue with each other about the progress, problems, and follow-up programs in each of their assigned areas.

Convergent communication models can also be found when a team of consultants both provincial consultants and district facilitators conducts field visits. During the field visit, it enabled the consultants to have direct dialogue with the village community regarding the progress, problems, and follow-up to the implementation of the program in their area. The convergent communication model was more intense when the village facilitator facilitated the excavation of ideas in the village through the focused group discussion method, where village facilitators as meeting facilitators provided the most extensive opportunity for the community to attend focused group discussion meetings to convey priority ideas in the development of their villages.

\subsection{Barriers to Inter-Stakeholders Communication in the Implementation of the Village Fund Programs}

Regarding communication barriers, this study explained the communication barriers that occur in 
communication from top to bottom, bottom up, horizontal, and diagonal. There are various types of communication barriers that occur in implementing village funds, namely: personal barriers, cultural barriers, physical barriers, environmental barriers. Personal barriers are obstacles that occur in communication participants, both communicators, and communicants. Personal obstacles in communication include attitudes, emotions, stereotyping, prejudice, bias, and others.

Cultural problems can also cause communication barriers. Communication made with people who have different cultures and backgrounds requires that someone understand the differences in terms of values, beliefs, and attitudes held by others. Cultural barriers include language, trust, and belief. Language barriers occur when people who communicate do not use the same language, or do not have the same level of language ability. Barriers can also occur when using a level of language that is not appropriate or when using a term that is not understood by one or more people invited to communicate. Another thing that contributes to the occurrence of language barriers is the situation in which conversations occur and the field of experience or frame of reference possessed by participants in communication regarding the subject matter of discussion.

Physical problems can also be a barrier to communication. Some physical disorders can affect the effectiveness of communication. Physical barriers to communication include telephone calls, the distance between individuals, and others. However, these physical barriers can generally be overcome. In addition to physical problems, the environment can also be a capable determinant of communication. Humans cause not all communication barriers as communication participants. Several environmental factors also influence the effective communication process. The message conveyed by the communicator can experience obstacles triggered by environmental factors, namely the physical background or situation where communication occurs. These environmental barriers include the level of activity, level of comfort, disturbance, and time.

\subsection{Village Fund Programs: History, Policy and Its Implementation}

Historically, the village fund program cannot be separated from various poverty reduction programs that have ever existed. The previous programs were the president instructions of the disadvantaged region, a development acceleration program for underdeveloped regions, regional empowerment in overcoming the impact of the economic crisis, social security networks, farmer business credit, kecamatan development program, and the most recent is the national program for community empowerment in rural areas. All of these programs place village communities as the subject of the development of their villages.

Village funds are philosophically aimed at improving prosperity and equitable distribution of rural development through improving public services in the village, advancing the village economy, overcoming inter-village development gaps and strengthening rural communities as subjects of development (Kementerian Keuangan, 2016).

The legal basis for implementing village funds is regulated in the following set of laws and government regulations: i) law number 6 of 2014 concerning villages; ii) government regulation no. 43/2014 concerning the implementation of law number 6/2014; iii) government regulation no. 47/2015 concerning an amendment to government regulation no. 43/2014; iv) government regulation no. 60/2014 concerning village funds sourced from the state budget of income and expenditures; v) government regulation no. 22/2015 concerning an amendment to government regulation no. $60 / 2015$; vi) village minister regulation no. 21/2015 concerning prioritizing the use of 2016 village funds; vii) village minister regulation no. 2/2015 concerning village meetings; and vii) minister of finance's bolt no. 247/PMK.07/2015 regulates technical matters related to allocation, distribution, use, monitoring, and evaluation of village funds.

The use of village funds considers the following priority principles: 1) justice, prioritizing the rights or interests of all villagers without discrimination; 2) priority needs, prioritizing village interests that are more urgent, more needed and directly related to the interests of most of the village community; and 3) village typology, taking into account the circumstances and the specific geographical, sociological, anthropological, economic and ecological characteristics of the village, as well as changes or developments in the progress of the village (Kemendes, 2016).

Village funds according to the minister of finance regulation number 49 of 2016 concerning the management, distribution, use, monitoring and evaluation of village funds, are funds originating from the state revenue and expenditure budget intended for villages that are transferred through the district/city regional revenue and expenditure budget and is used to finance government administration, implementation of development, community development, and community empowerment.

Village fund management in presidential regulation no. 60 of 2014 concerning village funds sourced from the 
state budget and expenditure article 2 states that village funds are managed in an orderly manner, comply with statutory provisions, are efficient, economical, transparent and responsible by paying attention to a sense of justice and propriety and prioritizing the interests of the local community.

Village funds in its implementation require the participation of all village communities, starting from the stages of planning, implementation, monitoring, to preservation. In line with the minister of finance regulation number 49 concerning procedures for allocating, distributing, using, monitoring and evaluating village funds article 22 paragraph 2 which states that the activities funded from the village fund are prioritized to be carried out in self-management using local resources or raw materials, and endeavored by absorbing more labor from the local village community.

It is intended to realize the true nature of village development, which according to the Republic of Indonesia Minister of Home Affairs Regulation Number 114 of 2014 concerning village development guidelines is an effort to improve the quality of life for the greatest welfare of the village community. The implementation of the village fund program is inseparable from the intention of poverty alleviation in the village as well as improving the welfare and quality of life of the village community. It is explained in law no. 6 of 2014 concerning villages that the purpose of village development is to improve the welfare of rural communities and the quality of human life and poverty alleviation through the fulfillment of basic needs, development of village facilities and infrastructure, development of local economic potential, and sustainable use of natural and environmental resources.

Village development planning is the process of stages of activities organized by the village government by involving the village consultative body and community elements in a participatory manner to utilize and allocate village resources in order to achieve village development goals. Planning village fund programs covering what will be funded through village funds is carried out by village communities with assistance from consultants in this case village facilitators. Planning in village financial management begins with the preparation of the village revenue and expenditure budget. The village revenue and expenditure budget that has been prepared was then agreed upon by the village government together with the village consultative body and stipulated in village regulations. Before the preparation of the village revenue and expenditure budget was carried out, the village government first drafted and established the village medium-term development plan. It contains the vision and mission of the village head, the direction of village development policy, and the plan of activities covering the field of village administration, village development implementation, village community development, and empowerment of village communities.

Empirical facts at the research location, the planning stage involves village communities by participating in attending meetings. The meeting in the framework of the planning phase began at the hamlet level to gather ideas for activities in each hamlet and was decided at the village meeting level. The village level meeting decision is the proposed priority activity to be carried out.

The implementation of activities, as at the planning stage, involved village communities as the main subject of village development. In connection with this, in the village, the team of implementation is formed whose management consists of the chairman, secretary, and treasurer, who are chosen by the village community themselves from the village community, and for the village community themselves. The formation and selection of the implementation team were carried out in the village level forum. At the research location, village funds are intended for three fields, namely the field of village administration, village development, and empowerment of village communities. The implementation of team operations in carrying out their duties get $3 \%$ of the funds managed. For example, if the implementation team carries out the construction of a farming road with a budget allocation of IDR 100 million, then it has the right to receive operational IDR 3 million. Furthermore, as transparency and accountability in the implementation of village funds, the implementation team is required to submit a funding accountability report to the community through a forum for accountability meetings in the village.

Monitoring is intended to ensure the implementation of the work carried out by the implementation team goes according to the applicable rules and local village agreements that are decided through village meetings. In its implementation at the village level an activity monitoring team was formed. Preservation of activities that have been carried out through village funds requires the participation of villagers to preserve them. A training team was formed in each activity involving the community users of the activity for achieving the goal.

\section{Conclusion}

Stakeholders in implementing village fund programs carry out formal and non-formal communication patterns. Formal communication patterns can take place from top to bottom, bottom up, horizontally, or diagonally. The 
non-formal communication pattern is a communication channel that does not pay attention to the hierarchy, rank, and position.

The model of communication among stakeholders in the implementation of village fund programs can be found in both linear and convergent models. This study explains that communication barriers in implementing village fund programs can occur in communication from top to bottom, from the bottom up, horizontally, and diagonally. There are various types of communication barriers that occur in implementing village funds, namely: personal barriers, cultural barriers, physical barriers, and environmental barriers.

Implementation of village funds requires the participation of all village communities, starting from the stages of planning, implementation, monitoring, to preservation. It is so that the villagers are the subject of the development of their village.

\section{References}

Bappenas. (2017). Dana Desa dan Penanggulangan Kemiskinan. Jakarta: Bappenas.

Cangara, H. (2000). Komunikasi Politik Khalamatak dan Efek. Bandung: Remaja Rosdakarya

Djamarah, B. S. (2004). Pola Komunikasi Orang Tua dan Anak di dalam Keluarga. Jakarta: PT. Reneka Cipta

Effendy, O. U. (2002). Ilmu Komunikasi Teori dan Praktek. Bandung: PT. Remaja Rosdakarya.

Indrawati, S. M. (2017). Kata Pengantar (dalam Buku Pintar Dana Desa). Jakarta: Kemenkeu RI

Kemendes. (2016). Pokok-Pokok Kebijakan Penggunaan Dana Desa Tahun 2016. Jakarta: Kemendes.

Kemendes. (2018). Peraturan Menteri Desa, Pembangunan Daerah Tertinggal, dan Transmigrasi Republik Indonesia. Jakarta: Kemendes

Kementerian, K. (2016). Kebijakan Pengalokasian dan Penyaluran Dana Desa. Jakarta: Kementerian Keuangan.

Kreitner, R., \& Kinicki, A. (1995). Organizational Behaviour (3rd ed.). United States: Richard D. Irwin Inc

Ludlow, R., \& Panton, F. (1996). The Essence of Effective Communication (terjemahan Deddy Jacobus). Yogyakarta: Andi.

Mardikanto, T. (1987). Komunikasi Pembangunan. Surakarta: Sebelas Maret University Press.

Moleong, L. J. (2007). Metodologi Penelitian Kualitatif(Edisi Revisi). Bandung: PT. Remaja Rosda Karya

Muhammad, A. (2004). Komunikasi Organisasi. Jakarta: Bumi Aksara.

Patton, M. Q. (1990). Qualitative Evaluation and Research Method (2nd ed.). Newbury Park, CA: Sage

Purwanto, D. (2003). Komunikasi Bisnis. Jakarta: Erlangga.

Rakhmat, J. (1998). Psikologi Komunikasi. Bandung: Remaja Rosdakarya.

Rogers, E. M., \& Kincaid, D. L. (1981). Communication Network: Toward a New Paradigm for Research. London: The Free Press, Collier Macmillan Publisher.

Rogers, E. M., \& Rogers, R. A. (1976). Communication in Organization. New York: The Free Press.

Ruliana, P. (2014). Komunikasi Organisasi: Teori dan Studi Kasus. Jakarta: Rajawali Press.

Satori, D., \& Komariah, A. (2014). Metodologi Penelitian Pendidikan. Jakarta: Bumi Aksara

Siahaan, S. M. (1991). Komunikasi Pemahaman dan Penerapannya. Jakarta: BPK Gunung Mulia

Soekanto, S. (2010). Pengantar Penelitian Hukum. Jakarta: UI Press

Sugiyono. (2009). Memahami Penelitian Kualitatif. Bandung: CV. Alfabeta

Sugiyono. (2015). Memahami Penelitian Kualitatif. Bandung: CV. Alfabeta

\section{Copyrights}

Copyright for this article is retained by the author, with first publication rights granted to the journal.

This is an open-access article distributed under the terms and conditions of the Creative Commons Attribution license (http://creativecommons.org/licenses/by/4.0/). 